\title{
Antibodies to Candida albicans in human cervicovaginal secretions
}

\author{
J. DOROTHY MILNE AND D. W. WARNOCK \\ From the Departments of Venereology and Microbiology, Bristol Royal Infirmary, Bristol
}

SUMmaRY The incidence of $\operatorname{IgA}$ and $\operatorname{IgG}$ antibodies against Candida albicans was determined in cervicovaginal secretions from 95 non-pregnant women. IgG antibodies were detected in $21 \cdot 2 \%$ of women with vaginal candidosis, in $23.5 \%$ of women harbouring yeasts in the vagina without clinical signs of infection, and in $26.6 \%$ of women not harbouring yeasts in the vagina. $\operatorname{IgA}$ antibodies were found in $6.1 \%$ of women with vaginal candidosis, in $5.9 \%$ of women harbouring yeasts in the vagina without clinical signs of infection, and in $8.9 \%$ of women not harbouring yeasts in the vagina. IgG antibodies against $C$. albicans were detected in the serum of all 95 women. It is suggested that a proportion of the antibodies found in the secretions was derived from the circulation.

\section{Introduction}

Candida albicans is a common cause of superficial cutaneous or mucosal infection in man. C. albicans is important as a pathogen because of its high incidence in normal persons in whom it forms part of the normal microbial flora of the mouth and intestinal tract. In women, vaginal candidosis is a common condition and this had led to interest in the use of serological tests as adjuncts to the usual clinical and microbiological methods of diagnosis of this infection (Stanley and Hurley, 1974; Warnock and Hilton, 1976; Jones and Warnock, 1977).

Antibodies to $C$. albicans have sometimes been detected in human cervical mucus (Parish et al., 1967) or cervicovaginal secretions (Govers and Girard, 1972; Waldman et al., 1972a). These antibodies have been found to belong to the $\operatorname{IgA}$ and IgG classes of immunoglobulin (Govers and Girard, 1972; Waldman et al., 1972a). It has been suggested that these antibodies might be the product of a local immunological response in the genital tract: application of $C$. albicans antigen to the cervical epithelium has been found to lead to the appearance of IgA and some IgG antibodies in the cervicovaginal secretions of normal women (Waldman et al., 1972b).

Address for reprints: Dr D. W. Warnock, Department of Microbiology, Bristol Royal Infirmary, Bristol BS2 8HW

Received for publication 12 April 1977
There is no information regarding the occurrence of IgA or IgG antibodies against $C$. albicans in the cervicovaginal secretions of women with proved vaginal candidosis. The incidence of these antibodies in the cervicovaginal secretions of women with vaginal candidosis and of other women is compared in this paper.

\section{Patients and methods}

\section{SUBJECTS}

Altogether 95 non-pregnant patients aged between 18 and 46 years were studied. These patients consisted of: 33 women with vaginal candidosis; these women had clinical signs of vaginitis or vulvovaginitis (vaginitis was recorded if any part of the vaginal mucosa was reddened or granular, vulvitis was recorded if any part of the vulva was reddened, swollen, fissured, or ulcerated) and a positive vaginal culture (C. albicans (31), Candidida tropicalis (1), Torulopsis glabrata (1)); 17 women with no clinical signs of vulvitis or vaginitis but with a positive vaginal culture (C. albicans (16), C. tropicalis (1)); and 45 women with no clinical signs of vulvitis or vaginitis and a negative vaginal culture. None of these women had received local antifungal treatment during the preceding month.

The patients were further divided into two groups: those who were using oral contraceptives (in all cases this was a combined oestrogen/progestogen pill) and those who were not. 
COLLECTION OF SPECIMENS

Five millilitres of blood were taken from each patient and the serum was separated and stored at $-20^{\circ} \mathrm{C}$ until studied. A cervicovaginal washing was taken from each woman: $10 \mathrm{ml}$ physiological saline was instilled into the cervical os and about $8 \mathrm{ml}$ of mucus and saline were then aspirated. The washings were stored at $-20^{\circ} \mathrm{C}$ until required, then centrifuged to remove debris, and concentrated 50 times using a Minicon B-15 concentrator (Amicon).

\section{ANTIGEN PREPARATION}

One strain of $C$. albicans group A (London School of Hygiene and Tropical Medicine 3153), maintained on glucose peptone medium, was used throughout this investigation. This strain was selected because it contains all the antigens of C. albicans group B and C. tropicalis (Hasenclever, 1965), and because it has antigens in common with T. glabrata (Hasenclever and Mitchell, 1960).

A cell suspension was prepared using $0.4 \%$ formal saline to harvest the cells. The suspension was diluted to 12000 cells per $\mathrm{ml}$ and stored at $4^{\circ} \mathrm{C}$ until used. One drop of this cell suspension was placed on each clean glass slide, dried at room temperature, and then flamed.

\section{INDIRECT IMMUNOFLUORESCENCE TEST}

Doubling dilutions of serum from 1:4 were made with phosphate buffered saline $(\mathrm{pH} \mathrm{7 \cdot 2)}$. One drop of each serum dilution or concentrated cervicovaginal secretion to be tested was placed on each antigen preparation. The slides were incubated for $30 \mathrm{~min}$ at $37^{\circ} \mathrm{C}$ in a moist chamber before being rinsed in phosphate buffered saline for $10 \mathrm{~min}$. Fluorescein-conjugated sheep anti-human $\operatorname{IgA}$ or IgG (Wellcome), diluted 1:5 with buffered saline, was placed on each slide and left for $30 \mathrm{~min}$ at $37^{\circ} \mathrm{C}$. The slides were rinsed in buffered saline and then mounted in buffered glycerol.

The highest dilution of serum giving a complete ring of bright green fluorescence around the cells was taken as the titre of the serum. In cases of doubt the test was repeated. Antibodies to $C$. albicans were considered to be present in samples of concentrated secretions if a definite ring of bright green fluorescence was visible around the cells.

\section{ABSORPTION OF SECRETIONS}

Sheep antiserum specific for human IgA or IgG (Wellcome) was added to samples of concentrated secretions containing IgA or IgG antibodies against C. albicans and incubated at $37^{\circ} \mathrm{C}$ for three hours and then at $4^{\circ} \mathrm{C}$ overnight. The absorbed samples were then centrifuged and the supernatant used in the immunofluorescence test.

\section{Results}

The incidence of $\operatorname{IgA}$ and $\operatorname{IgG}$ antibodies to $C$. albicans in the cervicovaginal secretions of the 95 patients is summarised in Table 1. The $\chi^{2}$ test was used to calculate the significance of the results.

\section{ANTIBODIES IN PATIENTS USING ORAL} CONTRACEPTION

There was no significant difference $\left(\chi_{2}^{2}=2 \cdot 349\right.$, $\mathbf{P}<\mathbf{0 . 5 0 )}$ in the incidence of IgG antibodies against C. albicans when women with vaginal candidosis were compared with women harbouring yeasts in the vagina without clinical signs of infection and with women not harbouring yeasts in the vagina, Similarly there was no significant difference $\left(\chi_{2}{ }^{2}=\right.$ $1.003, P<0.70)$ in the incidence of $\operatorname{IgA}$ antibodies when women with vaginal candidosis were compared with the other women.

\section{ANTIBODIES IN PATIENTS NOT USING ORAL} CONTR ACEPTION

There was no significant difference $\left(\chi_{2}^{2}=1 \cdot 490\right.$, $\mathbf{P}<0.50)$ in the incidence of $\mathrm{IgG}$ antibodies against C. albicans when women with vaginal candidosis were compared with women harbouring yeasts in the vagina without clinical signs of infection and with women not harbouring yeasts in the vagina. IgA antibodies were found in one woman with vaginal candidosis.

Table 1 Comparison of the incidence of $\operatorname{IgG}$ and $\operatorname{Ig} A$ antibodies to $\mathrm{C}$. albicans in cervicovaginal secretions of patients grouped according to diagnosis and the use of oral contraception

\begin{tabular}{|c|c|c|c|c|c|c|}
\hline & \multicolumn{3}{|c|}{ No oral contraception } & \multicolumn{3}{|c|}{ Oral contraception } \\
\hline & \multirow{2}{*}{$\begin{array}{l}\text { No. } \\
\text { of } \\
\text { patients }\end{array}$} & \multicolumn{2}{|c|}{ No. of patients with } & \multirow{2}{*}{$\begin{array}{l}\text { No. } \\
\text { of } \\
\text { patients }\end{array}$} & \multicolumn{2}{|c|}{ No. of patients with } \\
\hline & & $\begin{array}{l}\text { IgG } \\
\text { antibodies }\end{array}$ & $\begin{array}{l}\text { IgA } \\
\text { antibodies }\end{array}$ & & $\begin{array}{l}\text { IgG } \\
\text { antibodies }\end{array}$ & $\begin{array}{l}\operatorname{IgA} A \\
\text { antibodies }\end{array}$ \\
\hline \multirow{3}{*}{$\begin{array}{l}\text { Vaginal candidosis } \\
\text { No signs of infection yeast } \\
\text { present in vagina } \\
\text { No signs of infection, no } \\
\text { yeast in vagina }\end{array}$} & 10 & 4 & 1 & 23 & 3 & 1 \\
\hline & 7 & 2 & 0 & 10 & 2 & 1 \\
\hline & 12 & 2 & 0 & 33 & 10 & 4 \\
\hline
\end{tabular}


EFFECT OF ORAL CONTRACEPTION ON THE INCIDENCE OF ANTIBODIES IN SECRETIONS IgG antibodies against $C$. albicans were detected in 15 of 66 women using oral contraception compared with eight of 29 women who were not $\left(\chi_{1}{ }^{2}=0.259\right.$, $\mathbf{P}<0 \cdot 70)$. IgA antibodies were detected in six women using oral contraception and in one woman who was not $\left(\chi_{1}{ }^{2}=0.940, \mathrm{P}<0.50\right)$.

EFFECT OF TIME IN THE MENSTRUAL CYCLE ON THE INCIDENCE OF ANTIBODIES IN SECRETIONS

IgG antibodies against $C$. albicans were detected in eight of 29 women not using oral contraception. Antibodies were found in three of five women seen between days 1 and 10 of the menstrual cycle, in one of nine women seen between days 11 and 20, and in four of 15 women seen between days 21 and 30 . The differences in incidence were not significant $\left(\chi_{2}{ }^{2}=3 \cdot 861, \mathrm{P}<0.30\right)$.

\section{IMMUNOFLUORESCENCE TESTS ON}

\section{ABSORBED SECRETIONS}

Nineteen samples of cervicovaginal secretions containing IgG antibodies against $C$. albicans were absorbed with sheep antiserum specific for human IgG. This resulted in the complete elimination of specific IgG fluorescence. There was no increase in specific IgA fluorescence after absorption of the IgG antibodies. Seven samples of secretions containing IgA antibodies to $C$. albicans were absorbed with antiserum specific for human $\operatorname{IgA}$. This resulted in the complete elimination of specific IgA fluorescence. These tests established the specific nature of the reaction in the immunofluorescence test.

ANTIBODIES AGAINST $C$. ALBICANS IN SERUM The relationship between the titre of circulating IgG antibodies against $C$. albicans and the presence of IgG antibodies in cervicovaginal secretions is presented in Table 2. IgG antibodies were detected

Table 2 Serum IgG titres of antibodies to C. albicans of patients grouped according to diagnosis and the presence of $\operatorname{IgG}$ antibodies in cervicovaginal secretions

\begin{tabular}{|c|c|c|c|c|c|}
\hline & \multirow{2}{*}{$\begin{array}{l}\text { IgG antibodies } \\
\text { in secretions }\end{array}$} & \multicolumn{4}{|c|}{$\begin{array}{l}\text { Titre of serum } \operatorname{IgG} \\
\text { antibodies to C. albicans }\end{array}$} \\
\hline & & $1: 4$ & $1: 8$ & $1: 16$ & $1: 32$ \\
\hline \multirow[t]{2}{*}{ Vaginal candidosis } & Absent & 16 & 5 & 5 & 0 \\
\hline & Present & 0 & 1 & 5 & 1 \\
\hline \multirow{2}{*}{$\begin{array}{l}\text { No signs of infection, } \\
\text { yeasts present in } \\
\text { in vagina }\end{array}$} & Absent & 9 & 2 & 2 & 0 \\
\hline & Present & 2 & 1 & 1 & 0 \\
\hline \multirow{2}{*}{$\begin{array}{l}\text { No signs of infection, } \\
\text { no yeasts in vagina }\end{array}$} & Absent & 23 & 6 & 4 & 0 \\
\hline & Present & 4 & 4 & 0 & 0 \\
\hline
\end{tabular}

in the secretions of 12 of the 73 women with a serum IgG titre of $1: 4$ or $1: 8$ compared with 11 of the 22 women with a serum IgG titre of $1: 16$ or $1: 32$ $\left(\chi_{1}{ }^{2}=10 \cdot 351, \mathrm{P}<0 \cdot 01\right)$.

\section{Discussion}

This investigation has demonstrated that IgG antibodies against $C$. albicans can be detected in the cervicovaginal secretions of some women with vaginal candidosis $(21 \cdot 2 \%)$. This incidence was similar to that observed in women harbouring yeasts in the vagina without clinical signs of infection $(23.5 \%)$ and also to the incidence observed in women not harbouring yeasts in the vagina $(26 \cdot 6 \%)$.

Altogether, IgG antibodies against $C$. albicans were detected in the cervicovaginal secretions of $22.0 \%$ of the women harbouring yeasts in the vagina. These antibodies could be the product of a local immunological response: local production of IgG antibodies against $C$. albicans has been demonstrated in normal women (Waldman et al., 1972b). However, the presence of IgG antibodies in a similar proportion of women not harbouring yeasts in the vagina $(26.6 \%)$ suggests that these antibodies might not be the product of a local response.

C. albicans is part of the normal microbial flora of the mouth and intestinal tract and its presence on mucosal surfaces is often sufficient to stimulate the production of circulating antibodies in normal persons (Lehner, 1966; Warnock and Hilton, 1976; Jones and Warnock, 1977). The women in this investigation all had circulating IgG antibodies against $C$. albicans.

Is it possible that the IgG antibodies to $C$. albicans that were detected in the cervicovaginal secretions of our patients originated from the serum? The immunoglobulin content of the cervical mucus of individual women has been observed to change under endogenous hormonal influence (Schumacher, 1973) and it has been suggested that considerable amounts of serum IgG enter the cervicovaginal secretions of normal women (Schumacher, 1974).

Most of the women in this investigation were taking combination oral contraceptives. Chipperfield and Evans (1975) detected higher concentrations of $\operatorname{IgG}$ and $\operatorname{IgA}$ in the cervical mucus of normal women using these contraceptives than in similar women not using oral contraceptives. Increased IgG:IgA ratios were detected in women using combination oral contraceptives, and this led to the suggestion that the hormonal effect is manifested through increased transudation of IgG from the circulation.

Our findings indicate that oral contraceptives do not affect the incidence of IgG antibodies to $C$. 
albicans in cervicovaginal secretions. This does not mean that these contraceptives did not increase the concentration of IgG in the cervical mucus of individual women. The higher incidence of IgG antibodies in the cervicovaginal secretions of women with higher titres of circulating antibodies against C. albicans does suggest that these antibodies might be derived from the serum.

IgA antibodies against $C$. albicans were detected in the cervicovaginal secretions of a small proportion of the women in this investigation. $\operatorname{IgA}$ antibodies were detected in $6.1 \%$ of the women with vaginal candidosis and this incidence was similar to that observed in women harbouring yeasts in the vagina without clinical signs of infection $(5.9 \%)$ and also to the incidence observed in women not harbouring yeasts in the vagina $(8.9 \%)$. Local production of IgA antibodies against $C$. albicans has been demonstrated (Waldman et al., 1972b), but the presence of such antibodies in women not harbouring yeasts in the vagina suggests that these antibodies might not be the product of a local response.

IgA antibodies to $C$. albicans have been detected in the serum of normal persons (Lehner, 1970) and cervical mucus is thought to contain some $\operatorname{IgA}$ that has been derived from the circulation (Schumacher, 1974). Thus, it is reasonable to assume that a variable proportion of the $\operatorname{IgA}$ antibodies detected in the cervicovaginal secretions of our patients originated from the serum.

IgG and IgA antibodies to $C$. albicans can be detected in the serum of most normal persons but these antibodies do not appear to protect the host against $C$. albicans infection. Local production of IgA and IgG antibodies to $C$. albicans has been demonstrated in the genital tract of normal women
(Waldman et al., 1972b), but our observations suggest that antibodies derived from the circulation are also present in cervicovaginal secretions.

\section{References}

Chipperfield, E. J., and Evans, B. A. (1975). Effect of local infection and oral contraception on immunoglobulin levels in cervical mucus. Infection and Immunity, 11, 215-221.

Govers, J., and Girard, J. P. (1972). Some immunological properties of human cervical and vaginal secretions. Gynecologic Investigation, 3, 184-194.

Hasenclever, H. F. (1965). The antigens of Candida albicans. American Review of Respiratory Diseases, 92, Supplement, 150-158.

Hasenclever, H. F., and Mitchell, W. O. (1960). Antigenic relationships of Torulopsis glabrata and seven species of the genus Candida. Journal of Bacteriology, 79, 677-681.

Jones, G. R., and Warnock, D. W. (1977). Observations on the use of the double diffusion test in the diagnosis of vaginal candidiasis. Journal of Clinical Pathology, 30, 262-265.

Lehner, T. (1966). Immunofluorescence study of Candida albicans in candidiasis, carriers and controls. Journal of Pathology and Bacterio$\log y$, 91, 97-104.

Lehner, T. (1970). Serum fluorescent antibody and immunoglobulin estimations in candidosis. Journal of Medical Microbiology, 3, 475-481.

Parish, W. E., Carron-Brown, J. A., and Richards, C. B. (1967). The detection of antibodies to spermatozoa and to blood group antigens in cervical mucus. Journal of Reproduction and Fertility, $13,469-483$.

Schumacher, G. F. B. (1973). Soluble proteins of human cervical mucus. In Cervical Mucus in Human Reproduction, pp. 93-113. Edited by M. Elstein, K. S. Moghissi, and R. Borth. Scriptor Copenhagen.

Schumacher, G. F. B. (1974). In Immunological Approaches to Fertility Control, pp. 302-305. Edited by E. Diczfalusy. Karolinska Institutet: Stockholm.

Stanley, V. C., and Hurley, R. (1974). Candida precipitins in pregnant women: validity of the test systems used. Journal of Clinicat Pathology, 27, 66-69.

Waldman, R. H., Cruz, J. M., and Rowe, D. S. (1972a). Immuno= globulin levels and antibody to Candida albicans in human cervicovaginal secretions. Clinical and Experimental Inmmunology, 10, $427-434$.

Waldman, R. H., Cruz, J. M., and Rowe, D. S. (1972b). Intravaginal immunization of humans with Candida albicans. Journal of Immuno$\log y, 109,662-664$.

Warnock, D. W., and Hilton, A. L. (1976). Value of the indirect immunofluorescence test in the diagnosis of vaginal candidiasis. British Journal of Venereal Diseases, 52, 187-189. 